Brit. F. industr. Med., 1967, 24, 152.

\title{
An Evaluation of the Safety of Shrouded Nozzles used on High-pressure Greasing Equipment
}

\author{
R. MORLEY \\ From H.M. Factory Inspectorate, Newcastle upon Tyne
}

High-pressure grease guns using a shrouded nozzle were 'fired' from varying distances at amputated lower limbs to determine the pressure at which penetration of the skin occurred. It was concluded that a shrouded nozzle would not normally give rise to injury if the grease pressure was below 7,000 lbf./sq. in. (492 kgf./cm. ${ }^{2}$ ).

Rees (1937), Brooke and Rooke (1939), and Smith (1939) reported injuries to the fingers and hand from the injection of grease and oil by (I) the misapplication of high-pressure grease guns used in the maintenance of motor vehicles and (2) the testing of diesel injectors. Smith (1964) considered that the effect of the high-pressure injection of grease into the tissues was the result of physical distension (with consequent arterial compression) and chemical irritation. He reported that gangrene was a common result.

When high-pressure grease guns are operated, a sudden release of grease at a pressure of up to 10,500 lbf./sq. in. (738 kgf. $/ \mathrm{cm}^{2}$ ) occurs. In handoperated grease guns, the pressure build-up is much slower, and the muscle power required to operate a hand gun matches the strength required to apply the grease gun to the nipple.

The Figure shows diagrammatically the types of grease gun nozzles available. In types A (unshrouded) and B (shrouded), the velocity of the grease is increased by being delivered through a constriction. Type $B$ differs from $A$ in that the delivery nozzle is shrouded, and a collet guides the nozzle of the gun on to the grease nipple, whereas in A, accurate application of the nozzle to the nipple depends upon the operator. Type $C$ is known as the hydraulic type; it is both shrouded, held on to the nipple by a collet, and uses a large-bore nozzle. In type $\mathrm{D}$ (slide-on), the nozzle of the gun slides on to the nipple and differs from the preceding types in two respects: there is no constriction in the grease channel, and accurate application is ensured by the interlocking of the nozzle and nipple.

Received for publication August 4, 1966.
Smith (1964) showed that the unshrouded nozzle, type $A$, was unsafe as it was liable to slip off the nipple and penetrate the skin. His work also suggested that the grease pressure was high enough to force the grease through the skin even when there was no contact between the skin and the nozzle. No information was available on the minimum grease pressure required to penetrate the intact skin, or the maximum distance at which penetration would occur with a given grease pressure. Smith (1964) reports a case where an operator fired a gun from a distance at his hand to obtain some grease, thereby causing an injury.

Some manufacturers of high-pressure grease guns supply type A to special order only, preferring type C. Other manufacturers do not supply type A. In 43 garages a total of 54 nozzles was seen in use: seven (13\%) of type $A ; 16(30 \%)$ of type B; $25(46 \%)$ of type C; and six (II \%) of type D.

No injuries from types $\mathrm{C}$ or $\mathrm{D}$ have been reported to H.M. Factory Inspectorate. Injuries have been reported with type $A$ but no information as to the dangers or otherwise of type B (shrouded) is available.

These experiments were designed to obtain this information for shrouded nozzles without having to wait for injuries to occur and to be reported.

\section{Apparatus}

The apparatus used was a mobile greasing apparatus consisting of a grease drum, pump, and grease compressor operated by compressed air and rubber hose connecting to the grease gun and the nozzle. The gun had a pistol grip and the shrouded nozzle was as illustrated (Figure). Two manufact152 
An Evaluation of the Safety of Shrouded Nozzles used on High-pressure Greasing Equipment I53
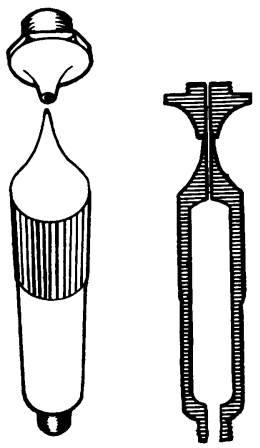

Type A (unshrouded)
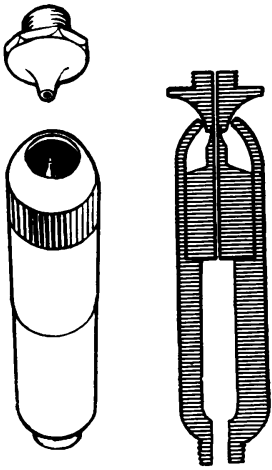

Type B (shrouded)

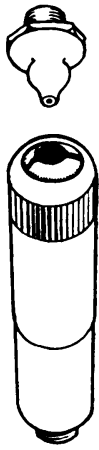

Type C (hydraulic)
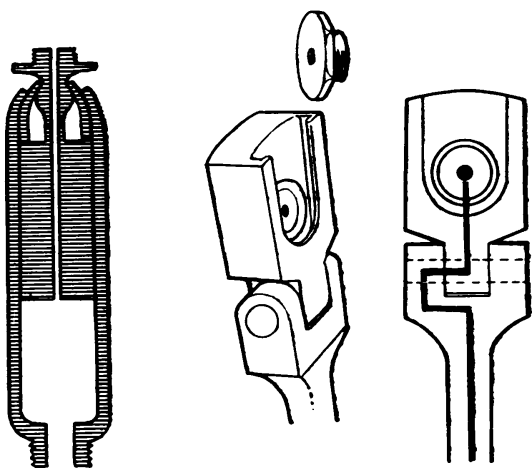

Type D (slide-on)

Figure. Types of nozzle used on grease guns.

urers kindly loaned equipment but both types were not available at the same time nor were the nozzles interchangeable. The grease was 'Shell Barbatia 2 Grease'. The first equipment used had a maximum pressure of $6,500 \mathrm{lbf}$. $/ \mathrm{sq}$. in. $\left(457 \mathrm{kgf} . / \mathrm{cm}^{2}\right)$ and, in Tables $I$ and II, is identified as nozzle ' $x$ '. The second equipment produced a maximum pressure of $10,500 \mathrm{lbf} . / \mathrm{sq}$. in. $\left(738 \mathrm{kgf} . / \mathrm{cm}^{2}{ }^{2}\right)$. This is nozzle ' $y$ ' in the Tables.

\section{Method}

Amputated legs (below the knee amputations for gangrene or arterial disease) were used. Within an hour of amputation the limb was enclosed in a polythene bag to prevent splattering of the grease, and the nozzle of the high-pressure grease gun was applied, at varying distances estimated visually, through a slit about half an inch long in the bag. The nozzle was held at right angles to the skin surface, either touching or at a distance away. The gun was 'fired' at macroscopically normal skin and subcutaneous tissue. The number of 'firings' per limb was limited to I4 to I9, partly on account of damage to the skin and tissues, and also to grease fouling of the skin.

\section{Results}

A total of 89 shots was 'fired' at five different limbs, at varying distances. No penetration of the skin occurred until a pressure of $7,700 \mathrm{lbf}$./sq. in. $\left(54 \mathrm{I} \mathrm{kgf.} / \mathrm{cm}^{2}\right)$ was reached; 48 shots at 6,500 and $7,000 \mathrm{lbf} . / \mathrm{sq}$. in. (457 and $492 \mathrm{kgf} . / \mathrm{cm} .{ }^{2}$ ) were all negative. At $7,700 \mathrm{lbf}$./sq. in. $40 \%$ of the shots penetrated, and this percentage increased to $100 \%$ at the two highest pressures available, namely 9,800 and $10,500 \mathrm{lbf} . / \mathrm{sq}$. in. (689 and $738 \mathrm{kgf} . / \mathrm{cm}^{2}$ ). These results are given in Table $I$.

Table II shows the degree of penetration according to an arbitrary scale which is defined.

\section{Discussion}

The unknown factor in these experiments was the physical state of the skin. This depends on such factors as age, sex, body build, and the part of the leg or foot at which the shot was fired. Ideally, a hand should have been used but these are rare and none was amputated whilst the equipment was available. From the work done on 'old' limbs, and not reported here, whilst the equipment was being tested, it appeared that skin resistance to penetration increased as the leg cooled and the skin dried. To avoid a possible error from this cause, all the shots were 'fired' at a leg within an hour of amputation. Muscular contraction still occurred during this period and it appeared justifiable to consider the limb as 'living' as far as skin resistance to trauma was concerned (Leading article, 1966).

Penetration became more difficult to achieve the more the angle of incidence decreased from a right angle. This effect is well known in the behaviour of projectiles. To evaluate this, precision mounting would have been required for the gun and the limb. To avoid this, all shots were fired at as near a right angle as possible.

Depth of penetration and the effects of local anatomy were not studied, partly because this was beyond the scope of this work but also because such results on a leg would have been of little practical value. An arm, and especially the hand, would have 
TABLE I

\begin{tabular}{|c|c|c|c|c|c|c|c|c|}
\hline \multirow{2}{*}{$\frac{\text { Nozzle }}{\mathrm{x}}$} & \multirow{2}{*}{$\begin{array}{l}\text { Limbs }^{1} \\
\text { A and B }\end{array}$} & \multirow{2}{*}{$\begin{array}{c}\begin{array}{c}\text { Grease Pressure } \\
(\mathrm{lbf} . / \mathrm{sq} . \text { in. }) \\
\left(\mathrm{kgf} / \mathrm{cm} .{ }^{2}\right)\end{array} \\
6,500(457)\end{array}$} & \multirow{2}{*}{$\begin{array}{l}\begin{array}{l}\text { No. of Shots } \\
\text { Fired }\end{array} \\
43\end{array}$} & \multirow{2}{*}{$\begin{array}{c}\begin{array}{c}\text { No. of Shots } \\
\text { Penetrated } \\
\text { Skin }\end{array} \\
\text { Nil }\end{array}$} & \multicolumn{2}{|c|}{$\begin{array}{l}\text { Distances between } \\
\text { which Shots were } \\
\text { Fired } \\
\text { (in.) (mm.) }\end{array}$} & \multicolumn{2}{|c|}{$\begin{array}{c}\text { Greatest Distance } \\
\text { at which Penetration } \\
\text { Occurred }^{2} \\
\text { (in.) } \quad(\mathbf{m m} .)\end{array}$} \\
\hline & & & & & $0-1$ & $0-6.3$ & & \\
\hline $\mathbf{y}$ & $\begin{array}{l}D \text { and } E \\
D \text { and } E \\
D \text { and } E \\
D \text { and } E \\
C \text { and } E \\
C\end{array}$ & $\begin{array}{r}7,000(492) \\
7,700(54 \mathrm{I}) \\
8,400(59 \mathrm{I}) \\
9,100(640) \\
9,800(689) \\
10,500(738)\end{array}$ & $\begin{array}{r}5 \\
5 \\
\text { II } \\
9 \\
10 \\
6\end{array}$ & $\begin{array}{r}\text { Nil } \\
2 \\
5 \\
7 \\
10 \\
6\end{array}$ & $\begin{array}{r}0 \\
0 \\
0-9 \\
0-9 \\
0-6 \\
0\end{array}$ & $\begin{array}{c}0 \\
0 \\
0-228 \\
0-228 \\
0-152 \\
0\end{array}$ & $\begin{array}{l}0 \\
9 \\
9 \\
6 \\
0\end{array}$ & $\begin{array}{c}0 \\
228 \\
228 \\
152 \\
0\end{array}$ \\
\hline
\end{tabular}

1A. Male, aged 57, healthy skin and subcutaneous tissue; vascular disease

B. Male, aged $6 \mathrm{I}$, healthy skin with generalized oedema; gangrenous toe and heel

C. Male, aged 80 , healthy skin and subcutaneous tissue; vascular disease

D. Female, aged 75 , healthy skin and subcutaneous tissue; vascular disease

E. Male, aged 38, healthy skin and subcutaneous tissue; vascular disease

[Description of skin applies only to that used for the 'shots'.]

${ }^{2}$ No attempt was made to determine the maximum distance at which penetration of the skin would occur, at any grease: pressure.

TABLE II

\begin{tabular}{|c|c|c|}
\hline Nozzle & $\begin{array}{c}\text { Grease Pressure } \\
(\text { lbf./sq. in }) \\
\left(\text { kgf./sq. cm. } .^{2}\right)\end{array}$ & $\begin{array}{c}\text { Degree of Penetration } \\
\text { of Grease into the } \\
\text { Limb }\end{array}$ \\
\hline $\mathbf{x}$ & $6,500(457)$ & 0 \\
\hline $\mathrm{y}$ & $\begin{array}{r}7,000(492) \\
7,700(541) \\
8,400(591) \\
9,100(640) \\
9,800(689) \\
10,500(738)\end{array}$ & $\begin{array}{l}\quad 0 \\
I \text { and } 4 \\
1,2 \text {, and } 3 \\
1,2,3 \text {, and } 4 \\
2 \text { and } 3 \\
2 \text { and } 3\end{array}$ \\
\hline
\end{tabular}

${ }^{1} \circ$ No penetration. Skin unmarked after cleansing of surface grease with cotton wool. Serial skin sections prepared from one of above negative shots (graphite-containing grease) showed no penetration microscopically.

I Puncture wound of skin, 'tattooing' with grease extending up to $0.5 \mathrm{~cm} .^{2}$ by area.

2 Puncture wound of skin. Subcutaneous injection of approximately $\mathrm{I}-4 \mathrm{~cm} .^{3}$ of grease.

3 Puncture wound of skin. Subcutaneous injection of approximately 4-10 $\mathrm{cm}^{3}$ of grease. This amount causes 'ballooning' of the skin.

4 Puncture wound of skin. Subcutaneous injection of over ro cm. ${ }^{3}$ of grease. 'Ballooning' approximately $2 \times 1 \frac{1}{2} \times \mathrm{I}$ in. $(50 \times 37 \times 25 \mathrm{~mm}$.) high.

[Penetration of grease into the muscle occurred in types 2 to 4 . It required an incision for its demonstration and this was not done with each shot due to the damage caused to the limb.]

been well worth studying if only one had become available.

It could be said, however, that on the sole of the foot and where skin overlaid bone, as over the tibia, penetration was more difficult.
The results indicate that, with the shrouded nozzle, penetration occurs with the nozzle resting on the skin at a pressure greater than $7,000 \mathrm{lbf}$./ sq. in. (492 kgf. $/ \mathrm{cm}^{2}{ }^{2}$ ). At a distance, the danger point appears to lie between 7,700 and $8,400 \mathrm{lbf}$./sq. in. (54I and $59 \mathrm{I} \mathrm{kgf.} / \mathrm{cm}^{2}$.). (It should be emphasized that these pressures are static pressures at the moment of 'firing'. If the trigger is kept depressed, the pressure falls rapidly to half its value unless there is some obstruction, i.e., the nipple or, in the accidental cases we are considering, the tissues.) It thus appears that at pressures below 7,000 lbf./sq. in. (492 kgf. $\left./ \mathrm{cm}^{2}\right)$ and with the standard bore, a shrouded nozzle is unlikely to cause an injury whether held on the skin or at a distance when it is fired. Further, these pressure measurements were made on the comparatively thin skin of the leg, and a factor increasing safety would be the greater strength of the skin of the hand, though no direct evidence is adduced to support this.

\section{Conclusion}

A shrouded nozzle (with the nozzle flush or recessed in the shroud) should be safe in all except the most unusual circumstances when the initial grease pressure is kept below 7,000 lbf./sq. in. (492 kgf. $\left./ \mathrm{cm}^{2}\right)^{2}$.

I should like to express my thanks to Dr. T. A. Lloyd Davies, H.M. Senior Medical Inspector of Factories, who suggested this investigation; Mr. E. W. Hodgson, H.M. Senior Engineering Inspector of Factories, and Mr. J. T. Toogood, H.M. Engineering Inspector of 
An Evaluation of the Safety of Shrouded Nozzles used on High-pressure Greasing Equipment I55

Factories, for much advice and encouragement; Professor A. G. Hepplestone, Department of Pathology, University of Newcastle upon Tyne, in whose Department the work was done; and Tecalemit (Engineering) Ltd. and Laycock Engineering Co. Ltd., for loaning the necessary equipment.
REFERENCES

Brooke, R., and Rooke, C. J. (1939). Brit. med. F., 2, I186. Leading article (1966). Frozen human skin. Ibid., 1, 374 .

Rees, C. E. (1937). F. Amer. med. Ass., 109, 866.

Smith, F. H. (1939). Ibid., 112, 907.

Smith, M. G. H. (1964). Brit. med. J., 2, 918.

\section{The January Issue}

The January (1967) issue contains the following papers:-

Chronic Bronchitis in Miners and Non-miners: an Epidemiological Survey of a Community in the Gold-mining Area in the Transvaal G. K. Sluis-Cremer, L. G. Walters, and H. S. SICHEL

Ventilatory Function in Relation to Mining Experience and Smoking in a Random Sample of Miners and Non-miners in a Witwatersrand Town G. K. Sluis-Cremer, L. G. Walters, and H. S. SICHEL

Prevalence of Chronic Respiratory Disease in a Pulp Mill and a Paper Mill in the United States B. G. FERRIS, JR., W. A. BURGESS, and J. WORCESTER

Effects of Histamine Aerosol in Byssinotic Subjects Aly A. E. Massoud, R. E. C. Altounyan, J. B. L. HowelL, and R. E. LANE

A Noise-attenuating Enclosure for Audiometer Earphones R. R. A. Coles

Heat-protective Ventilated Jackets: A Comparison of Humid and Dry Ventilating Air G. W. CROCKFORD and D. E. LEE

Further Investigations on the Evaluation of Exposure to Nitrobenzene J. PIoTRowskI

Long-term Efficacy of Oil-adjuvant Influenza Vaccine in an Industrial Population R. W. HOWELL

Determination of the Carboxyhaemoglobin Saturation of Blood by Spectrophotometric Analysis J. M. Beeckmans

Miscellanea

Mercury Poisoning and Its Treatment with N-acetyl-D, L-Penicillamine V. Parameshvara

An Inorganic Mercury Hazard in the Manufacture of Artificial Jewellery J. F. CoPPLESTONE and D. A. MCARTHUR

Book Reviews

A number of copies are still available and may be obtained from the Publishing Manager, British

Medical Association, Tavistock Square, W.C.I, price I8s. $6 d$. 